\title{
Kecemasan Siswa Sekolah Menengah Pertama Dalam Menyelesaikan Masalah SPLDV Pada Kelas Virtual
}

\author{
Evi Sri Hastuti $\mathbb{D}^{\text {| Khoerul Umam }}$ | Lawrence Eclarin ${ }^{(D)}$ | Krisna Satrio Perbowo
}

How to cite: Hastuti, S., H., Umam, K., Eclarin, L,\& Perbowo, K., S., 2021. K Kecemasan Siswa Dalam Menyelesaikan Masalah Modelling Matematika Pada Praktek Kelas Virtual. International Journal of Progressive Mathematics Education. 1(1).64-84. https://doi.org/10.22236/ijopme.v1i1.6914

To link to this article : https://doi.org/10.22236/ijopme.v1i1.6914

@2021. The Author(s). This open access article

(6) is distributed under a Creative Commons Attribution (CC BY-SA) 4.0 license. Athibution (CC BY-SA) 4.0 license.

曲 Published Online on March 12, 2021

至 Submit your paper to this journal

View Crossmark data 『 


\title{
Kecemasan Siswa Sekolah Menengah Pertama Dalam Menyelesaikan Masalah SPLDV Pada Kelas Virtual
}

\author{
Evi Sri Hastuti ${ }^{1}$, Khoerul Umam ${ }^{1 *}$, Lawrence Eclarin ${ }^{2}$, Krisna Satrio Perbowo ${ }^{3}$
}

Received: 23 Desember 2020 Accepted: 1 Maret 2021 Published Online: 11 Maret 2021

\begin{abstract}
Abstrak.
Latar Belakang Pembelajaran matematika yang membutuhkan interaksi yang sangat aktif antara guru dan siswa melalui komunikasi tatap muka secara tiba-tiba harus berubah. Siswa dan guru berkomunikasi melalui meeting online dan komunikasi secara virtual. Hal ini menimbulkan potensi kecemasan yang muncul pada diri siswa. Tujuan dari penelitian mengeksplorasi sejauh mana kecemasan siswa terjadi pada pembelajaran matematika materi SPLDV. Pemilihan Subjek Penelitian dilakukan dengan memilih subjek yang menggunakan pembelajaran matematika dengan virtual dalam jangka waktu yang lama. Metode Penelitian menggunakan penelitian kuantitatif dengan menggunakan survey untuk mengungkapkan bagaimana kecemasan yang terjadi pada siswa. Analisis Data Hasil Penelitian dilakukan dengan mendeskripsikan hasil dari survey yang sudah diberikan oleh siswa. Hasil tersebut dikolaborasikan dengan penelitian terdahulu sehingga dapat memberikan kontribusi atas kecemasan yang terjadi. Hasil penelitian ini menunjukkan bahwa kecemasan matematis siswa banyak dipengaruhi oleh faktor lingkungan yakni rasa tidak percaya diri siswa pada kemampuannya dan merasa bahwa orang lain memiliki kemampuan matematis yang lebih logis.
\end{abstract}

Kata kunci: Kecemasan Matematis, SPLDV,

(c) (1) (2) 2021. The Author(s). This open access article is distributed under a Creative Commons Attribution (CC BY-SA) 4.0 license.

Evi Sri Hastuti

evi.sri.hastuti.students@uhamka.ac.id

$\varangle$ Khoerul Umam

khoerul.umam@uhamka.ac.id

Lawrence Eclarin

mathdept@mmsu.edu.ph

Krisna Satrio Perbowo

k.perbowo@warwick.ac.id

1 Progam Studi Pendidikan Matematika, Universitas Muhammadiyah Prof. DR. HAMKA, Indonesia

2 Department of Mathematics, Mariano Marcos State University

3Warwick University, United Kingdom. 


\section{Latar Belakang Masalah}

Penilaian negatif siswa terhadap matematika yang disertai dengan kesulitan dalam pembelajaran dapat menimbulkan kecemasan matematika (Beilock \& Maloney, 2015; Winarso \& Haqq, 2019; Zientek et al., 2010). Kecemasan matematika dapat mengalihkan konsentrasi dalam menyelesaikan permasalahan sehingga siswa cenderung menghindari matematika (Kargar et al., 2010). Penghindaran matematika ini secara tidak sadar dapat dikarenakan asumsi-asumsi siswa yang menganggap matematika merupakan pelajaran yang sulit dan tidak menyenangkan sehingga memungkinkan siswa dapat merasa kesulitan dan cemas dalam pembelajaran matematika di kelas dan menyebabkan hambatan dalam belajar. Wahid et al., (2014) menunjukan bahwa siswa dengan tingkat kecemasan matematika yang tinggi memiliki hasil belajar dan kemampuan matematika lebih rendah dibandingkan siswa yang tidak memiliki kecemasan matematika.

Ashcraft (2002) mendefinisikan kecemasan sebagai bentuk perasaan tegang, khawatir atau takut sehingga dapat berpengaruh pada kemampuan matematika. Namkung et al., (2019) menambahkan kecemasan matematika adalah perasaan emosional yang dapat menghalangi minat, motivasi dan self regulation siswa sehingga berpengaruh pada pandangan dan kemampuan matematika seseorang. Kecemasan dapat membawa dampak positif atau negatif, misalnya dalam hal pelaksanaan ujian. Siswa yang memiliki kecemasan positif akan mempersiapkan ujian dengan semaksimal mungkin sehingga akan mendapatkan sesuatu sesuai keinginannya, sedangkan siswa yang memiliki kecemasan negatif akan membayangkan hal-hal negatif mengenai ujian sehingga memungkinkan siswa kesulitan dalam berkonsentrasi dan memahami materi pembelajaran. Hal ini dapat terjadi karena kecemasan membuat siswa menjadi ragu dengan kemampuannya dalam memahami matematika (Rozgonjuk et al., 2020; Sherman \& Wither, 2003; Sloan, 2010).

Sevindir et al., (2014) dalam penelitiannya menunjukan bahwa beberapa siswa yang mengerjakan soal matematika terindikasi mengalami kecemasan yang ditunjukan dengan gejala jantung berdebar, sesak napas, sakit perut, berkeringat dan kehilangan konsentrasi sehingga merasa kesulitan dan gugup. Sieber menuturkan bahwa kecemasan dapat mengganggu kemampuan kognitif dalam belajar seperti berkonsentrasi, pembentukan konsep dan pemecahan masalah matematik (Winardi et al., 2019).

Adapun beberapa penyebab kecemasan yaitu pengaruh lingkungan sekitar, sekolah dan guru (Mann \& Walshaw, 2019). Salah satu contohnya yaitu ketika guru lebih mementingkan nilai dibandingkan pemahaman siswa dapat berakibat menurunnya rasa percaya diri pada siswa sehingga muncul kecemasan (Finlayson, 2014). Bentuk kecemasan ini akan dialami siswa saat diadakannya ujian atau menjawab pertanyaan di depan kelas (Ramirez et al., 2018). Penyebab kecemasan lainnya yaitu adanya pengalaman tidak menyenangkan saat di sekolah seperti dipermalukan didepan kelas saat bertanya dan konflik dengan guru matematika; rendahnya prestasi belajar; sikap negatif terhadap matematika; dan pengaruh orang tua seperti tidak mempercayai kemampuan matematika anaknya serta menuntut anaknya agar mendapat nilai sempurna dalam pelajaran matematika (Sloan, 2010). Hal-hal tersebut tentunya dapat menimbulkan pengalaman yang tidak menyenangkan bagi siswa dan cenderung selalu menghindari matematika. 
Menurut Fennema \& Sherman kecemasan juga muncul ketika seseorang takut atau ragu untuk mengubah angka dan simbol dalam memecahkan soal matematika (Winardi et al., 2019). Salah satu materi matematika yang membuat siswa merasa cemas adalah aljabar (Adams \& Holcomb, 1986; Ashcraft, 2002). Sloan (2010) dalam penelitiannya menunjukan bahwa siswa mengalami kesulitan pada aljabar dikarenakan pola pikir yang menganggap matematika itu sulit. Dalam jenjang sekolah menengah pertama, konsep aljabar dapat ditemui pada materi sistem persamaan linear dua variabel. Winardi (2019) menunjukan bahwa siswa yang mempelajari materi sistem persamaan linear dua variabel mengalami kesulitan ketika mengubah pernyataan masalah kontekstual menjadi simbol matematika dikarenakan adanya rasa tidak percaya diri yang disebabkan kecemasan. Lebih lanjut, kecemasan tersebut dapat disebabkan lantaran siswa menganggap bahwa matematika merupakan pelajaran yang sulit, siswa selalu gagal atau mendapat nilai tidak sempurna saat pembelajaran matematika, siswa selalu menulis dalam kelas matematika tanpa memperhatikannya, siswa merasa cemas dan gugup jika tidak mengerti, serta siswa kehilangan minat dalam pembelajaran matematika (Nyroos et al., 2015; Şengül \& Dereli, 2010; Vitasari et al., 2010).

Pemindahan metode belajar dalam lembaga pendidikan di Indonesia menjadi kelas virtual akibat pandemi covid-19 juga berdampak pada kecemasan siswa dalam pembelajaran virtual. Dhawan (2020) menyebutkan bahwa pembelajaran kelas virtual membuat siswa menjadi frustasi karena adanya ketidaksesuaian antara materi pembelajaran dan teknologi yang digunakan. Hal ini membuat peneliti tertarik untuk mendeskripsikan bagaimana kecemasan siswa sekolah menengah pertama dalam menyelesaikan masalah sistem persamaan linear dua variabel pada kelas virtual di era covid-19 ini. Berdasarkan fokus masalah tersebut, maka rumusan masalah dalam penelitian ini adalah:

1. Apakah terdapat kecemasan pada siswa sekolah menengah pertama dalam menyelesaikan masalah sistem linear dua variabel pada kelas virtual?

2. Faktor apakah yang mempengaruhi kecemasan siswa sekolah menengah pertama dalam menyelesaikan masalah sistem linear dua variabel pada kelas virtual?

\section{Kajian Teori}

\subsection{Kecemasan Matematika}

Kecemasan matematika adalah peningkatan respons emosional seseorang ketika berhadapan dengan situasi matematik seperti mengubah angka ke dalam pemecahan masalah matematika atau ketika berurusan dengan situasi evaluatif matematika sehingga mempengaruhi kemampuan matematikanya (Suárez-Pellicioni et al., 2016). Aarnos \& Perkkilä (2012) menambahkan kecemasan matematika merupakan reaksi emosional yang berasal dari lingkungan luar, diri sendiri dan ranah kognitif saat siswa berhadapan dengan matematika. Jadi kecemasan matematika adalah respon negatif seseorang terhadap matematika yang disebabkan faktor internal atau faktor eksternal sehingga dapat menjadi hambatan belajar di kelas. 
Finlayson (2014) menyebutkan gejala umum kecemasan matematika pada siswa, beberapa diantaranya yaitu jantung beredebar, gangguan pernafasan, berkeringat, menggigit kuku, gugup, sakit perut, kurang percaya diri, frustasi karena tidak berhasil, bingung karena tidak mendapatkan jawaban yang benar, dan merasa stress saat menjelang ujian. Menurut Elliot terdapat 3 tipe individu saat merasa cemas di situasi matematika, yakni (a) the memorizer's of mathematics, yaitu mampu mengingat rumus matematika namun tidak dapat menerapkan konsepnya. Pengahafalan rumus-rumus matematika sering terjadi ketika akan melaksanakan ujian atau test matematika. Tidak diterapkannya konsep matematika dapat membuat siswa lebih mudah lupa. Kebanyakan siswa hanya menghafal rumus matematika tanpa menerapkannya karena cemas jika mendapat nilai tidak sempurna; (b) the mathematics avoider, yaitu menghindari matematika. Kesulitan dalam memahami matematika membuat siswa cemas dalam proses belajar di kelas. Salah satu bentuk penghindaran matematika yaitu tidak masuk kelas matematika dan tidak menyukai segala sesuatu yang berkaitan dengan matematika; dan (c) the incompetent of mathematics in self professed, yaitu menganggap bahwa dirinya tidak memiliki kemampuan matematika.

Setiap siswa memiliki gejala kecemasan yang berbeda-beda, begitu pula dengan tingkat kecemasannya. Tingkat kecemasan seseorang bisa membawa dampak negatif atau positif tergantung tingkatannya yaitu ringan, sedang, atau berat. Menurut Peplau tingkat kecemasan terbagi menjadi empat, yakni (a) kecemasan ringan, yaitu kecemasan yang dialami dalam kehidupan sehari-hari. Tingkat kecemasan ringan ini dapat membantu seseorang dalam memotivasi belajar, mampu memecahkan masalah, dan menghasilkan pertumbuhan dan kreativitas karena adanya persepsi luas dalam dirinya; (b) kecemasan sedang yaitu kecemasan yang membuat persepsi seseorang menjadi sempit namun masih dapat mengerjakan perintah orang lain; (c) kecemasan berat yaitu kecemasan yang membuat seseorang tidak bisa berfikir tentang hal-hal lain, persepsinya sangat sempit dan perlu diarahkan untuk terfokus pada arah lain; dan (d) panik, yaitu hilangnya kontrol atau kendali atas diri sendiri sehingga tidak dapat melakukan sesuatu meskipun mendapat arahan orang lain. Panik biasanya disertai dengan gangguan karakter, meningkatnya keaktifan motorik dan kurangnya insensitas berhubungan dengan orang lain. Selain itu adanya penyimpangan persepsi yang dimiliki dan hilangnya pikiran rasional dan tidak berfungsi secara efektif.

Kecemasan dapat berdampak pada penghindaran serta pandangan siswa terhadap matematika. Menurut studi terdahulu, kecemasan juga berpengaruh terhadap prestasi dan kemampuan siswa dalam pembelajaran matematika. Oleh karena itu, perlu diketahui faktor kecemasan pada siswa. Beberapa faktor yang mempengaruhi kecemasan menurut Finlayson \& Jameson (2014) yakni (a) faktor personal, yaitu faktor mengenai proses kognitif, motivasi, afektif dan selektif perasaan/ emosi. Salah satu bentuk faktor personal yaitu perasaan takut dan tidak percaya diri terhadap kemampuan yang dimilikinya dan adanya kejadian masa lalu yang membuat trauma dengan matematika. Contoh lainnya yaitu seperti kurangnya motivasi belajar siswa, kurangnya kepercayaan diri dan kemampuan dalam matematika, malu bertanya, dan merasa rendah diri; 
(b) faktor lingkungan, yaitu berasal dari sikap guru, orang tua, atau lingkungan sekitarnya yang dapat mempengaruhi tingkat kecemasan siswa seperti orang tua yang selalu memuji anaknya dalam matematika akan mendapat kepercayaan diri sehingga kecemasan akan menurun; dan (c) faktor intelektual/ penilaian yaitu bakat dan tingkat kecerdasan yang dimiliki masing-masing siswa. Dalam hal ini, siswa cenderung merasa tidak percaya diri dengan kemampuan yang dimilikinya khususnya ketika pelaksanaan ujian berlangsung.

Kecemasan dalam pembelajaran matematika menjadi hal tidak biasa ketika siswa tidak dapat mengatasinya dengan baik. Siswa dapat kehilangan kepercayaan diri dalam mengerjakan matematika sehingga berdampak pada proses dan hasil belajar siswa. Menurut Finlayson (2014) terdapat dua cara dalam mengurangi kecemasan matematika yaitu:

a. Strategi personal

Beberapa hal yang dapat dilakukan siswa untuk mengurangi kecemasan yaitu mengembangkan teknik untuk rileks seperti latihan pernapasan, mendengarkan musik, atau menenangkan diri. Selain itu siswa dapat mengembangkan cara untuk menumbuhkan rasa percaya diri seperti mengaitkan matematika dengan ilmu pengetahuan lain, mengerjakan permasalahan matematika yang mudah terlebih dahulu baru permasalahan yang sulit serta memiliki sifat optimis. Cara lain yang digunakan untuk mengurangi kecemasan yaitu belajar matematika dirumah, selalu menyelesaikan tugas matematika, mengikuti pembelajaran matematika di kelas, menghafalkan rumus, dan tidak tertinggal dalam pembelajaran matematika. Dukungan guru dan orang tua juga dapat mengurangi kecemasan pada siswa seperti mengembangkan rasa percaya diri dan harga diri siswa seperti memberikan motivasi dalam belajar.

b. Strategi guru dalam mengajar

Dalam pembelajaran di kelas kecemasan timbul karena pendekatan pembelajaran yang berpusat pada guru. Hal ini mengakibatkan kurangnya konsep pemahaman dan pemecahan masalah pada siswa. Maka dari itu, lingkungan pembelajaran interaktif merupakan solusi yang tepat untuk mengurangi kecemasan matematika dengan membentuk rasa percaya diri pada siswa. Guru dapat mendorong setiap siswa untuk mengekspresikan ide-idenya, menunjukan bahwa ada banyak cara untuk menyelesaikan matematika, siswa dapat menggunakan metode pemecahan masalahnya sendiri, dan siswa tidak perlu merasa takut salah dalam menyelesaikan matematika.

\subsection{Pembelajaran Matematika Pada Kelas Virtual}

Pembelajaran matematika adalah serangkaian kegiatan terencana guna memberikan pengalaman belajar kepada peserta didik agar mencapai tujuan kompetensi pada materi matematika. Glaser menambahkan dalam pembelajaran matematika diperlukan untuk memperhatikan komponen pembelajaran seperti analisis kompetensi, keadaan pengetahuan, keterampilan yang akan dicapai, kesiapan siswa dalam memulai pembelajaran, prosedur penilaian (Gallagher, 1979). 
Kelas virtual atau yang biasa disebut sebagai pembelajaran daring adalah kegiatan belajar dalam lingkungan sinkron (konferensi audio/ video) atau asinkron (e-mail/ forum diskusi) yang menggunakan perangkat berbeda seperti komputer atau ponsel dan terhubung dengan koneksi internet (Dhawan, 2020). Kelas virtual dapat menciptakan kegiatan belajar mengajar yang inovatif dan fleksibel sehingga pembelajaran ini berpusat pada siswa (Dhawan, 2020). Beatrice Ghirardini (2015) menuturkan konten kelas virtual terbagi menjadi dua, yakni (a) simple learning resource, yaitu konten pembelajaran sederhana seperti power point, video atau audio. Konten pembelajaran seperti ini tidak menuntut siswa untuk berinteraksi dengan guru, biasanya siswa hanya menonton atau membacanya tetapi tujuan pembelajaran akan tetap tercapai; (b) interaktif e-lesson, yaitu pola pendekatan berbasis web. Konten Interaktif e-lesson meliputi teks, grafik, animasi audio, video dan adanya interaktivitas atau umpan balik dalam bentuk pertanyaan. Dari paparan yang telah dijabarkan dapat disimpulkan pembelajaran matematika pada kelas virtual merupakan kegiatan belajar matematika yang mana pembelajaran berpusat pada siswa dan melalui media pembelajaran daring tanpa adanya batasan waktu, ruang, dan sumber pembelajarannya. Konten pembelajaran matematika pada kelas virtual dapat menggunakan simple learning resource atau interaktif e-lesson sesuai kebutuhan para guru.

Menurut Lee (2007) \& Dhawan (2020) beberapa karakteristik atau ciri-ciri kelas virtual yaitu waktu dan lokasi belajar siswa diatur secara fleksibel; guru dapat mengajar dalam jumlah banyak; adanya kesadaran diri pada siswa agar cepat beradaptasi dengan kelas online; pembelajaran berpusat pada siswa; adanya pembelajaran interaktif dan komunikatif; pembelajaran daring memerlukan dukungan dari lembaga, program, kursus, siswa dan fakultas sehingga keberhasilan pembelajaran daring dapat tercapai. Dalam melaksanakan kelas virtual perlu diketahui prinsip-prinsip pembelajaran pada kelas virtual.

Menurut Anderson \& McCormick pada tahun 2005 prinsip yang harus diperhatikan dalam pembelajaran pada kelas virtual, yakni (a) penyesuaian kurikulum dengan memperhatikan tujuan pembelajaran, koherensi antara materi dan tujuan pembelajaran, kenyamanan dalam pembelajaran serta pemilihan metode belajar yang sesuai; (b) perancangan kegiatan belajar inklusif berdasarkan perbedaan kondisi sosial, suku dan jenis kelamin. Perancangan pembelajaran inklusif ini diharapkan dapat menyediakan bermacam-macam jenis dan tingkat pencapaian belajar yang diinginkan siswa; (c) adanya pembelajaran interaktif di kelas sehingga siswa dapat terlibat secara langsung dan dapat mencapai tujuan pembelajaran; (c) adanya pembelajaran berkualitas dengan teknologi inovatif pada kelas daring; (d) penggunaan beberapa desain pembelajaran sesuai karakteristik siswa, penggunaan fitur pembelajaran yang memicu proses metakognitif dan kolaborasi siswa serta adanya kesesuaian materi pembelajaran; (e) adanya umpan balik antara siswa mengenai hal yang harus ditemui dan evaluasi diri; (f) adanya penilaian hasil belajar sebagai penentu kelulusan ataupun panduan untuk siswa dalam memilih arah pendidikan ke jenjang selanjutnya; (g) kegiatan pembelajaran dilakukan secara konsisten berdasarkan tujuan, materi, dan asesmen. Materi yang diberikan harus relevan agar dapat mencapai tujuan pembelajaran serta penyusunan asesmen guna mengukur pencapaian tujuan; (h) menggunakan teknologi sederhana dan mudah dioperasikan tanpa perlu banyak pelatihan; dan (i) kegiatan pembelajaran daring harus dilaksanakan secara efektif dan efisein dalam hal biaya yang disertai dengan manfaat yang diperoleh. 
Dengan memperhatikan prinsip pembelajaran kelas virtual, pembelajaran diharapkan dapat berjalan sesuai dengan seharusnya. Selain itu, agar pembelajaran matematika dalam kelas virtual berjalan lancar, maka perlu diperhatikan faktor sukses pembelajaran kelas virtual. Menurut Beatrice Ghirardini (2015) faktor sukses pembelajaran kelas virtual, yakni (a) kurikulum pembelajaran kelas virtual disusun secara relevan dan sesuai kebutuhan siswa seperti keterampilan, pengetahuan dan informasi siswa; (b) konten pembelajaran kelas virtual disusun secara terpisah dengan konten pembelajaran konvensional guna menyusun penjadwalan waktu dalam pembelajaran kelas virtual; (c) menggunakan metode dan teknik pengajaran yang inovatif dan kreatif sehingga dapat mengembangkan pengalaman belajar baru pada siswa; (d) adanya interaktivitas antara guru dan siswa dalam pembelajaran kelas virtual; (e) guru memonitor kemajuan belajar dalam pembelajaran kelas virtual.

Kemajuan teknologi saat ini memudahkan pendidik dalam menciptakan kelas virtual matematika. Saat ini sangat banyak pencipta teknologi membuat aplikasi pendidikan yang memiliki fitur video call, share screen, merekam dan aplikasi pengumpulan tugas. Fitur tersebut mampu membuat penggunanya merasa tetap dekat dan interaktif meskipun pembelajaran dilaksanakan jarak jauh. Selain itu kelas virtual memiliki beberapa kelebihan diantaranya yaitu adanya fleksibilitas waktu dan lokasi pembelajaran, banyaknya aplikasi pembelajaran online yang mendukung, adanya kemudahan guru dalam menciptakan metode pembelajaran yang mengkombinasikan audio, video dan teks serta adanya lingkungan pembelajaran yang kolaboratif dan interaktif sehingga siswa dituntut untuk berpartisipasi dalam keaktifan di kelas (Dhawan, 2020; Gautreau et al., 2016; Zientek et al., 2010).

Di sisi lain, dalam penggunaan kelas virtual ini diperlukan pembelajaran yang berkualitas dan bermutu. Hal ini menjadi tantangan bagi seorang guru karena adanya pemindahan metode belajar dari konvensional menjadi daring membuat guru harus mengubah metodologi pembelajaran dan membuat siswa ikut aktif dalam kelas virtual. Selain itu dalam menciptakan keberhasilan pada kelas virtual matematika, kemandirian siswa memiliki peran penting sebagai penentu utamanya (Dhawan, 2020). Dengan kemandirian tersebut diharapkan siswa dapat memiliki kesadaran dalam mengatur waktu belajar matematika pada kelas virtual.

\subsection{Kecemasan Siswa Pada Materi SPLDV Dalam Kelas Virtual}

Kecemasan matematika merupakan respon emosional seseorang ketika berhadapan dengan situasi matematika. Kecemasan matematika dapat timbul karena adanya kesulitan yang dialami siswa dalam pembelajaran matematika. Menurut Tim LRN bagian yang paling sulit dalam matematika untuk dipahami siswa adalah koefisien, variabel, pemfaktoran, menggambar grafik, dan akar-akar. Aljabar merupakan konsep matematika yang berhubungan dengan koefisien dan variabel dengan aturan manipulasi angka atau simbol dalam matematika. Salah satu materi matematika yang menggunakan konsep aljabar yaitu materi sistem persamaaan linear dua variabel. Dalam materi sistem persamaan linear dua variabel ditemukan kesulitan dalam penyelesaian atau pemecahan masalah pada siswa. Nurdianti et al., (2019) menyebutkan faktor yang menyebabkan siswa kesulitan dalam materi sistem persamaan linear dua 
variabel yakni (a) tidak menguasai materi penunjang pelajaran membuat siswa sulit dalam menyelesaikan masalah yang diberikan; (b) adanya konsep-konsep matematika yang tidak dipahami siswa; (c) ketidakmampuan siswa dalam menghubungkan keterkaitan matematika dengan ilmu lain; dan (d) kurangnya pengaplikasian konsep matematika dalam kehidupan sehari-hari.

Kesulitan dalam penyelesaian materi sistem persamaan linear dua variabel tersebut dapat menyebabkan kecemasan pada siswa. Menurut Winardi et al., (2019) siswa yang merasa cemas dalam penyelesaian materi sistem persamaan linear dua variabel dikarenakan adanya rasa tidak percaya diri dalam belajar atau bergaul, merasa rendah diri karena tidak bisa mengerjakan materi tersebut sebaik teman-temannya, tidak mengingat atau memahami materi sistem persamaan linear dua variabel sehingga siswa merasa tegang dan sulit berkonsentrasi, adanya kebiasaan mencontek pekerjaan teman sehingga siswa menjadi ragu dengan kemampuannya, adanya tekanan sosial karena dikucilkan teman, siswa membenci pelajaran matematika, dan juga merasa bahwa semua temannya mengetahui jawaban atau memahami materi ini dengan baik kecuali dirinya. Kecemasan pada siswa merupakan hal yang harus diperhatikan karena dapat menghambat kegiatan pembelajaran terhadap proses dan hasil belajar siswa (Ashcraft, 2002). Oleh karena itu perlu diketahui cara mengatasi kecemasan yang dialami siswa ketika berhadapan dengan materi sistem persamaan linear dua variabel. Beberapa cara yang dapat dilakukan agar mengurangi kecemasan saat menyelesaikan materi sistem persamaan linear dua variabel yaitu dukungan dari teman sebaya dan juga penciptaan lingkungan belajar yang menyenangkan (Hanna \& Dempster, 2009; Jameson, 2014; Winardi et al., 2019).

Kecemasan tidak hanya terjadi pada kelas konvensional namun kecemasan juga ditemukan pada kelas virtual (Oktawirawan, 2020). Kelas virtual atau yang biasa disebut sebagai pembelajaran daring adalah kegiatan belajar dalam lingkungan sinkron (konferensi audio/ video) atau asinkron (e-mail/ forum diskusi) yang menggunakan perangkat berbeda seperti komputer atau ponsel dan terhubung dengan koneksi internet (Dhawan, 2020; Roux \& Nagel, 2018; Umam et al., 2019). Salah satu kelebihan kelas virtual yaitu adanya fleksibilitas dalam hal waktu dan lokasi. Adanya fleksibilitas dalam hal waktu dan lokasi tentunya memberikan kemudahan bagi dunia pendidikan karena dalam pembelajaran guru dan siswa tidak perlu bertatap muka dan pembelajaran dapat dilakukan dimana pun dan kapan pun. Namun, hal ini juga menjadi hal yang perlu diperhatikan karena dalam pembelajaran kelas virtual siswa perlu menerapkan sifat mandiri selama kegiatan belajar berlangsung. Kegiatan belajar yang fleksibel ini membuat siswa kurang memahami materi pembelajaran yang disampaikan jika tidak diiringi dengan sifat mandiri dalam belajar, akibatnya siswa merasa bingung dan tidak paham sehingga timbul frustasi dalam kelas virtual (Dhawan, 2020). Keadaan frustasi yang dialami siswa tersebut merupakan salah satu gejala kecemasan menurut Finlayson (2014).

Selain kurangnya kemandirian siswa dalam belajar, faktor pemicu kecemasan lainnya yaitu adanya kesulitan dalam pengerjaan tugas yang diiringi dengan waktu pengumpulan yang singkat, koneksi internet yang lemah atau tidak stabil sehingga siswa tertinggal materi pelajaran, adanya ketidakmampuan siswa untuk membeli kuota internet, adanya kendala teknis dalam aplikasi pembelajaran yang digunakan seperti tidak terkirimnya tugas, terlambat bergabung pada kelas virtual, dan juga tampilan visual dan audio yang tidak jelas (Oktawirawan, 2020). Beberapa cara yang dapat dilakukan agar mengurangi kecemasan saat 
kelas virtual yaitu meningkatkan kualitas belajar mandiri, tidak menumpuk tugas yang diberikan guru, melakukan diskusi dengan teman sebaya, berkonsultasi dengan guru mengenai kesulitan atau hambatan yang dialami saat pembelajaran kelas virtual, memiliki kualitas dan jam tidur yang baik, mendengarkan musik atau menonton film, berdoa, dan menggunakan provider yang mendukung agar koneksi internet menjadi stabil (Moore et al., 2011; Oktawirawan, 2020; Sahin, 2007).

Kecemasan dapat terjadi dalam pelaksanaan pembelajaran sistem persamaan linear dua variabel pada kelas virtual. Adanya kesulitan yang dialami siswa saat pembelajaran sistem persamaan linear dua variabel pada kelas konvensional dapat terjadi juga pada kelas virtual. Banyaknya kendala teknis yang terjadi pada kelas virtual seperti koneksi internet, tampilan visual dan audio yang kurang baik, atau pun gagalnya pengiriman tugas membuat siswa kesulitan dalam mengikuti pelajaran dikelas khususnya pada mata pelajaran matematika yang menyebabkan kecemasan matematika materi sistem persamaan linear dua variabel.

\section{Metode Penelitian}

Penelitian ini menggunakan pendekatan kuantitatif sedangkan metode penelitian yang digunakan dalam penelitian ini adalah survey. Menurut Hox \& Boeije (2005) survey digunakan ketika peneliti ingin mendapatkan informasi yang meliputi sikap, perasaan, pengalaman, pendapat, dan perilaku seseorang. Survey dilakukan dengan memberikan kuesioner yang berisi pernyataan mengenai kecemasan dan disebarkan melalui tautan elektronik google form. Tujuan utama dari penelitian ini adalah untuk mengetahui tingkat kecemasan pada siswa sekolah menengah pertama dalam menyelesaikan masalah sistem persamaan linear dua variabel pada kelas virtual dan faktor paling menonjol yang mempengaruhi kecemasan siswa sekolah menengah pertama dalam menyelesaikan masalah sistem persamaan linear dua variabel pada kelas virtual.

\subsection{Partisipan}

Sampel diperoleh dari 200 siswa sekolah menengah pertama (SMP) kelas VIII di daerah Jakarta, Bogor, Depok, Tangerang, dan Bekasi yang sedang melakukan pembelajaran daring pada kelas virtual serta sudah mempelajari materi sistem persamaan linear dua variabel. Partisipan juga diminta untuk mengisi mengenai hal yang berkaitan dengan pembelajaran daring seperti durasi belajar, teknologi yang digunakan saat pembelajaran daring serta kegiatan yang dilakukan selama pandemi.

\begin{tabular}{llcc} 
Tabel 1. Demografi Partisipant & & & \\
Demografi & & Label & N \\
\hline Jenis Kelamin & Laki-laki & L & 65 \\
& Perempuan & P & 135 \\
\hline \multirow{2}{*}{ Wilayah } & Jakarta & J & 157 \\
& Bogor & B & 12 \\
& Depok & D & 6 \\
\hline
\end{tabular}




\begin{tabular}{llcc}
\hline & Tangerang & T & 5 \\
& Bekasi & Bs & 20 \\
\hline Durasi Belajar Matematika & $<5$ jam & & 159 \\
& $10-15$ jam & & 31 \\
& $>15$ jam & Hp & 10 \\
\hline Teknologi yang digunakan & Handphone & Lp & 183 \\
& Laptop & Tb & 1 \\
& Tablet & Sa & 8 \\
\hline Aplikasi yang digunakan & Semuanya & GC & 179 \\
& Google Classroom & W & 103 \\
& WhatsApp & Ws & 35 \\
& Website dari sekolah & Wos & 16 \\
& Website luar sekolah & M & 29 \\
\hline
\end{tabular}

\subsection{Instrumen}

Instrumen yang digunakan yaitu kuesioner kecemasan matematika yang dimodifikasi dari Wahid et al., (2014) sesuai dengan materi penelitian ini yakni sistem persamaan linear dua variabel. Kuesioner berisi 30 pernyataan mengenai kecemasan dalam menyelesaikan masalah sistem persamaan linear dua variabel yang terdiri dari tiga faktor yaitu emosional, lingkungan dan penilaian. Item pernyataan kuesioner untuk faktor emosional dan penilaian menggunakan lima poin Skala Likert yaitu "sangat mirip seperti saya", "seperti saya", "agak seperti saya", "tidak seperti saya", dan "sangat tidak seperti saya" dengan poin tertinggi 5 yakni "sangat mirip seperti saya" dan poin terendah 1 yakni "sangat tidak seperti saya". Sedangkan Skala Likert item pernyataan kuesioner untuk faktor lingkungan yaitu "tidak pernah", "jarang", "kadang-kadang", "sering", dan "sangat sering" dengan poin tertinggi 5 yakni "sangat sering" dan poin terendah 1 yakni "tidak pernah".

\subsection{Teknik Pengumpulan Data}

Teknik pengumpulan data dalam penelitian ini menggunakan kuesioner. Adapun langkah-langkah pengumpulan data yaitu: (1) menyusun kuesioner kecemasan matematika yang dimodifikasi dari Wahid et al., (2014) sesuai dengan materi penelitian ini yakni sistem persamaan linear dua variabel; (2) menentukan sampel penelitian dengan menggunakan teknik purposive sampling; (3) menyebarkan kuesioner kepada siswa SMP kelas VIII yang sedang melakukan pembelajaran daring dan sudah mempelajari materi sistem persamaan linear dua variabel melalui tautan elektronik google form serta berdomisili di Jakarta, Bogor, Depok, Tangerang, Bekasi. 


\subsection{Data Analisis}

Untuk menentukan tingkat kecemasan siswa sekolah menengah pertama dalam menyelesaikan masalah sistem persamaan linear dua variabel maka digunakan statistik deskriptif yang diperoleh dari hasil kuesioner instrumen dengan menggunakan skor mean dan nilai standar deviasi. Kuesioner disebar kepada siswa sekolah menengah pertama kelas VIII yang sedang melakukan pembelajaran daring dan sudah mempelajari materi sistem persamaan linear dua variabel serta berdomisili di Jakarta, Bogor, Depok, Tangerang, Bekasi. Pengisian kuesioner dilakukan tanpa paksaan dan tidak menyebabkan risiko pada partisipan.

\section{Hasil Penelitian dan Pembahasan}

Statistik deskriptif digunakan untuk mengetahui tingkat kecemasan siswa dalam menyelesaikan masalah sistem persamaan linear dua variabel pada kelas virtual. Data yang digunakan berupa hasil kuesioner yang disebarkan melalui survey google form. Kecemasan siswa pada materi sistem persamaan linier dua variabel dibagi menjadi tiga faktor yaitu faktor emosional, faktor penilaian dan faktor lingkungan.

\section{Tabel 1. Faktor Emosional}

\section{Pernyataan}

Mean

SD Rank

$\begin{array}{llll}\text { Saya merasa tidak dapat mengontrol nilai matematika pada materi } & 2.93 & 1.032 & 1\end{array}$ sistem persamaan linear dua variabel.

Ketika mengerjakan atau memikirkan materi sistem persamaan linear $\begin{array}{llll}2.58 & 1.266 & 4\end{array}$ dua variabel maka jantung saya berdebar.

Saya merasa kesal ketika sedang mengerjakan atau memikirkan materi $\begin{array}{lll}2.88 & 1.201 & 2\end{array}$ sistem persamaan linear dua variabel.

$\begin{array}{llll}\text { Tangan saya akan berkeringat ketika mengerjakan atau memikirkan } & 2.10 & 1.156 & 6\end{array}$ materi sistem persamaan linear dua variabel.

$\begin{array}{lllll}\text { Saya merasa gugup ketika mengerjakan atau memikirkan materi sistem } & 2.73 & 1.218 & 3\end{array}$ persamaan linear dua variabel.

$\begin{array}{lllll}\text { Perut saya akan sakit ketika mengerjakan atau memikirkan materi } & 1.67 & 0.931 & 10\end{array}$ sistem persamaan linear dua variabel.

Otot saya menjadi tegang dan kaku ketika mengerjakan atau $1.81 \quad 0.994 \quad 8$ memikirkan materi sistem persamaan linear dua variabel.

$\begin{array}{llll}\text { Saya sulit tidur setelah mengerjakan materi sistem persamaan linear } & 2.05 & 1.217 & 7\end{array}$ dua variabel atau ketika besok ada pelajaran / ujian tentang sistem persamaan linear dua variabel. 


\begin{tabular}{l}
$\begin{array}{l}\text { Saya merasa lebih sering buang air kecil ketika berada di kelas } \\
\text { matematika atau ketika mengerjakan tugas/ ujian tentang sistem }\end{array}$ \\
$\begin{array}{l}\text { persamaan linear dua variabel. } \\
\begin{array}{l}\text { Ketika mengerjakan atau memikirkan materi sistem persamaan linear } \\
\text { dua variabel, kepala saya menjadi sakit atau leher saya menjadi kaku. }\end{array}\end{array}$ \\
\hline
\end{tabular}

Tabel 1. Memberikan ringkasan hasil kuesioner siswa pada faktor emosional. Secara umum, siswa setuju bahwa mereka tidak dapat mengontrol nilai matematika pada materi sistem persamaan linear dua variabel $(\mathrm{M}=2.93, \mathrm{SD}=1.032)$. Tidak terkontrolnya nilai yang didapat siswa disebabkan kecemasan. Hal ini sesuai dengan pendapat Beilock \& Maloney (2015) bahwa kecemasan menyebabkan menurunnya kinerja siswa sehingga berpengaruh terhadap hasil belajar atau prestasi siswa.

Salah satu penyebab siswa tidak dapat mengontrol nilai matematika pada materi sistem persamaan linear dua variabel yaitu karena kurangnya pemahaman konsep. Sejalan dengan Winardi et al., (2019) bahwa siswa yang merasa cemas dalam penyelesaian materi sistem persamaan linear dua variabel dikarenakan siswa tidak mengingat atau memahami materi sistem persamaan linear dua variabel, sehingga siswa merasa tegang dan sulit berkonsentrasi. Hal ini juga ditunjukan pada pernyataan "otot saya menjadi tegang dan kaku ketika mengerjakan atau memikirkan materi sistem persamaan linear dua variabel." ( $\mathrm{M}=1.81, \mathrm{SD}=0.994)$.

Lebih lanjut pernyataan "ketika mengerjakan atau memikirkan materi sistem persamaan linear dua variabel maka jantung saya berdebar." $(\mathrm{M}=2.58, \mathrm{SD}=1.266)$ dan pernyataan "perut saya akan sakit ketika mengerjakan atau memikirkan materi sistem persamaan linear dua variabel." $(\mathrm{M}=1.67, \mathrm{SD}=0.931)$ menggambarkan respon siswa secara emosional dan fisik saat berada di situasi cemas. Gejala kecemasan ini sesuai dengan pernyataan Finlayson (2014) bahwa jantung berdebar, sakit perut, berkeringat, gugup, bingung, stress dan sebagainya merupakan respon siswa ketika berada di situasi cemas. Pernyataan "saya merasa kesal ketika sedang mengerjakan atau memikirkan materi sistem persamaan linear dua variabel." $(\mathrm{M}=2.88$, $\mathrm{SD}=1.201)$ menunjukan adanya indikasi pengalaman negatif yang dialami siswa di kelas atau di lingkungannya. Hal itu sesuai dengan pendapat Winardi et al., (2019) dan Aarnos \& Perkkilä (2012) yang menyebutkan bahwa pengalaman negatif dapat membawa dampak buruk pada pandangan siswa terhadap matematika sehingga siswa tidak menyukai matematika dan selalu menghindari matematika. 


\section{Faktor Emosi}

\begin{abstract}
Ketika mengerjakan atau memikirkan materi sistem persamaan linear dua variabel, kepala saya menjadi sakit atau leher saya menjadi kaku.

Saya merasa lebih sering buang air kecil ketika berada di kelas matematika atau ketika mengerjakan tugas/ ujian tentang sistem persamaan linear dua variabel.

Saya sulit tidur setelah mengerjakan materi sistem persamaan linear dua variabel atau ketika besok ada pelajaran / ujian tentang sistem persamaan linear dua...

Otot saya menjadi tegang dan kaku ketika mengerjakan atau memikirkan materi sistem persamaan linear dua variabel.
\end{abstract}

Perut saya akan sakit ketika mengerjakan atau memikirkan materi sistem persamaan linear dua variabel.

Saya merasa gugup ketika mengerjakan atau memikirkan materi sistem persamaan linear dua variabel.

Tangan saya akan berkeringat ketika mengerjakan atau memikirkan materi sistem persamaan linear dua variabel.

Saya merasa kesal ketika sedang mengerjakan atau memikirkan materi sistem persamaan linear dua variabel.

Ketika mengerjakan atau memikirkan materi sistem persamaan linear dua variabel maka jantung saya berdebar.

Saya merasa tidak dapat mengontrol nilai matematika pada materi sistem persamaan linear dua variabel.

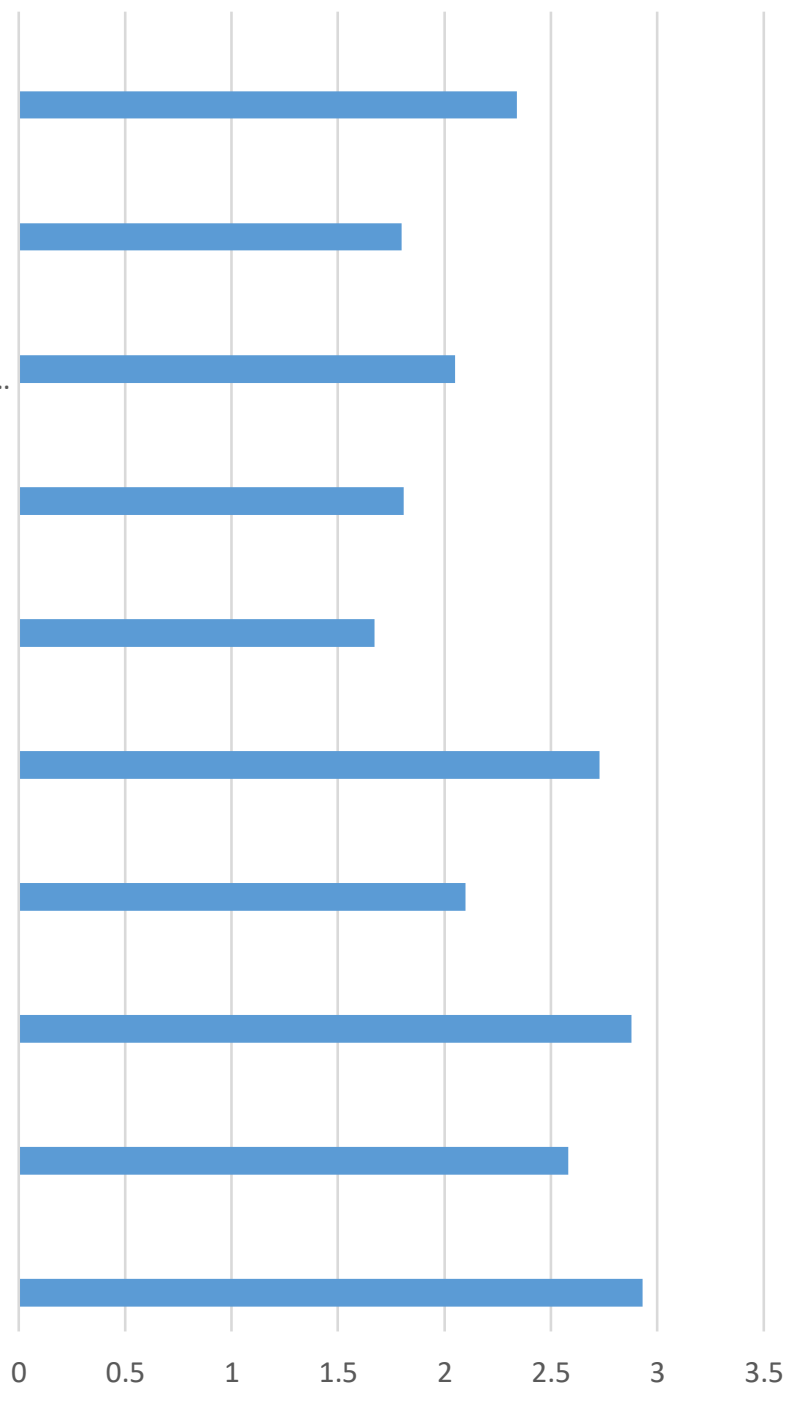

Pernyataan rata-rata kecemasan paling banyak pada siswa yaitu "saya merasa tidak dapat mengontrol nilai matematika pada materi sistem persamaan linear dua variabel." dengan nilai ( $\mathrm{M}=2.93, \mathrm{SD}=1.032)$. Sedangkan pernyataan rata-rata kecemasan paling sedikit pada siswa yaitu "perut saya akan sakit ketika mengerjakan atau memikirkan materi sistem persamaan linear dua variabel." ( $M=1.67, S D=0.931)$. Gangguan fisiologis yang terjadi tersebut dikarenakan adanya rasa tidak nyaman pada diri siswa sehingga menimbulkan kecemasan. Hal ini sesuai dengan pernyataan menurut Harari et al., (2013) bahwa kecemasan menimbulkan respons fisiologis negatif yang berakibat pada penghindaran matematika. Pada titik tertentu, penghindaran yang dialami siswa dapat memberikan dampak terhadap cara pandang dan pola berpikirnya terhadap matematika sehingga dapat mempengaruhi prestasi dan kinerja siswa dalam pembelajaran di kelas. Hal ini sesuai dengan pernyataan menurut Kargar et al., (2010) bahwa penghindaran matematika yang disebabkan kecemasan dapat mempengaruhi hasil belajar siswa. 


\section{Tabel 2. Faktor Penilaian}

\begin{tabular}{lcccc}
\multicolumn{1}{c}{ Pernyataan } & Mean & SD & Rank \\
\hline $\begin{array}{l}\text { Saya merasa sangat buruk dalam mengerjakan ujian matematika } \\
\text { pada materi sistem persamaan linear dua variabel. }\end{array}$ & 3.09 & 1.224 & 6 \\
\hline $\begin{array}{l}\text { Saya merasa bahwa saya perlu belajar lebih giat untuk ujian sistem } \\
\text { persamaan linear dua variabel dari pada ujian materi mata pelajaran }\end{array}$ & 3.85 & 1.148 & 1 \\
$\begin{array}{l}\text { lainnya. } \\
\text { Ujian materi sistem persamaan linear dua variabel lebih membuat }\end{array}$ & 2.90 & 1.203 & 8
\end{tabular}

saya stress dari pada ujian mata pelajaran lainnya.

Saat belajar untuk ujian materi sistem persamaan linear dua $\begin{array}{llll}2.50 & 1.152 & 10\end{array}$ variabel, saya menunjukan perilaku cemas.

Saya merasa memahami konsep materi sistem persamaan linear dua variabel saat belajar di kelas, namun saat ujian berlangsung saya mengerjakannya dengan sangat buruk.

\begin{tabular}{|c|c|c|c|}
\hline $\begin{array}{l}\text { Saya sulit konsentrasi saat mengerjakan ujian sistem persamaan } \\
\text { linear dua variabel. }\end{array}$ & 3.18 & 1.162 & 4 \\
\hline $\begin{array}{l}\text { Saya merasa tidak percaya diri ketika mengerjakan ujian sistem } \\
\text { persamaan linear dua variabel, meskipun saya sudah giat belajar. }\end{array}$ & 3.20 & 1.248 & 3 \\
\hline $\begin{array}{l}\text { Saya merasa tidak percaya diri dengan ide/ metode penyelesaian } \\
\text { saya saat mengerjakan ujian sistem persamaan linear dua variabel. }\end{array}$ & 3.07 & 1.197 & 7 \\
\hline $\begin{array}{l}\text { Secara umum saya merasa ujian mata pelajaran apapun adalah } \\
\text { pencerminan kelayakan saya sebagai seseorang. }\end{array}$ & 3.29 & 1.154 & 2 \\
\hline $\begin{array}{l}\text { Selama ujian sistem persamaan linear dua variabel, saya } \\
\text { membandingkan pekerjaan saya dengan orang sekitar. }\end{array}$ & 2.81 & 1.331 & 9 \\
\hline
\end{tabular}

Tabel. 2 memberikan ringkasan hasil kuesioner siswa pada faktor penilaian. Secara umum, siswa setuju bahwa mereka perlu belajar lebih giat untuk ujian sistem persamaan linear dua variabel dari pada ujian materi mata pelajaran lainnya $(M=3.85, S D=1.148)$. Hal ini sesuai dengan pendapat Mann \& Walshaw (2019) yang menyatakan bahwa ujian matematika membuat siswa merasa lebih cemas sehingga siswa perlu belajar giat untuk mempersiapkan ujian matematika. Kecemasan yang melebihi biasanya ini dikarenakan kurangnya pemahaman materi pada siswa, pandangan negatif siswa yang menganggap ujian matematika itu menakutkan atau sulit serta adanya persaingan nilai didalam kelas.

Sejalan dengan Finlayson (2014) yang memberikan pendapat bahwa kurangnya pemahaman materi saat ujian membuat siswa tidak bisa mengisi lembar ujian atau siswa seringkali lupa dengan langkah 
matematika saat pelaksanaan ujian, yang diperlihatkan dari pernyataan "saya merasa memahami konsep materi sistem persamaan linear dua variabel saat belajar di kelas, namun saat ujian berlangsung saya mengerjakannya dengan sangat buruk" $(M=3.14, S D=1.224)$. Hal ini tentunya dapat mempengaruhi hasil belajar siswa jika tidak dipersiapkan dengan baik.

Selain itu kecemasan juga mempengaruhi rasa percaya diri siswa (Sloan, 2010). Rendahnya rasa percaya diri siswa dalam mengerjakan ujian ditunjukan dari pernyataan "saya merasa sangat buruk dalam mengerjakan ujian matematika pada materi sistem persamaan linear dua variabel” $(M=3.09, S D=1.224)$, "saya merasa tidak percaya diri ketika mengerjakan ujian sistem persamaan linear dua variabel, meskipun saya sudah giat belajar" ( $M=3.20, S D=1.248)$, "saya merasa tidak percaya diri dengan ide/ metode penyelesaian saya saat mengerjakan ujian sistem persamaan linear dua variabel" ( $M=3.07, S D=1.197)$.

Rendahnya rasa percaya diri yang dimiliki siswa dapat menjadi suggest bahwa mereka tidak bisa mengerjakan matematika sehingga siswa menjadi ragu dengan kemampuannya dan merasa takut gagal. Ketakutan ini muncul karena adanya tuntutan orang tua yang ingin anaknya mendapat nilai bagus dalam pelajaran matematika. Hal ini sejalan dengan Sloan \& Vitasari et al., (2010) bahwa rasa percaya diri yang rendah dipengaruhi faktor orang tua. Hal ini dapat menjadi pengalaman negatif bagi siswa yang dapat mengakibatkan penghindaran terhadap matematika dan kehilangan minat belajar terhadap matematika. 


\section{Faktor Penilaian}

Selama ujian sistem persamaan linear dua variabel,

saya membandingkan pekerjaan saya dengan orang sekitar.

Secara umum saya merasa ujian mata pelajaran apapun adalah pencerminan kelayakan saya sebagai seseorang.

Saya merasa tidak percaya diri dengan ide/ metode penyelesaian saya saat mengerjakan ujian sistem persamaan linear dua variabel.

Saya merasa tidak percaya diri ketika mengerjakan ujian sistem persamaan linear dua variabel, meskipun saya sudah giat belajar.

Saya sulit konsentrasi saat mengerjakan ujian sistem persamaan linear dua variabel.

Saya merasa memahami konsep materi sistem persamaan linear dua variabel saat belajar di kelas, namun saat ujian berlangsung saya mengerjakannya...

Saat belajar untuk ujian materi sistem persamaan linear dua variabel, saya menunjukan perilaku cemas.

Ujian materi sistem persamaan linear dua variabel lebih membuat saya stress dari pada ujian mata pelajaran lainnya.

Saya merasa bahwa saya perlu belajar lebih giat untuk ujian sistem persamaan linear dua variabel dari pada ujian materi mata pelajaran lainnya.

Saya merasa sangat buruk dalam mengerjakan ujian matematika pada materi sistem persamaan linear dua variabel.

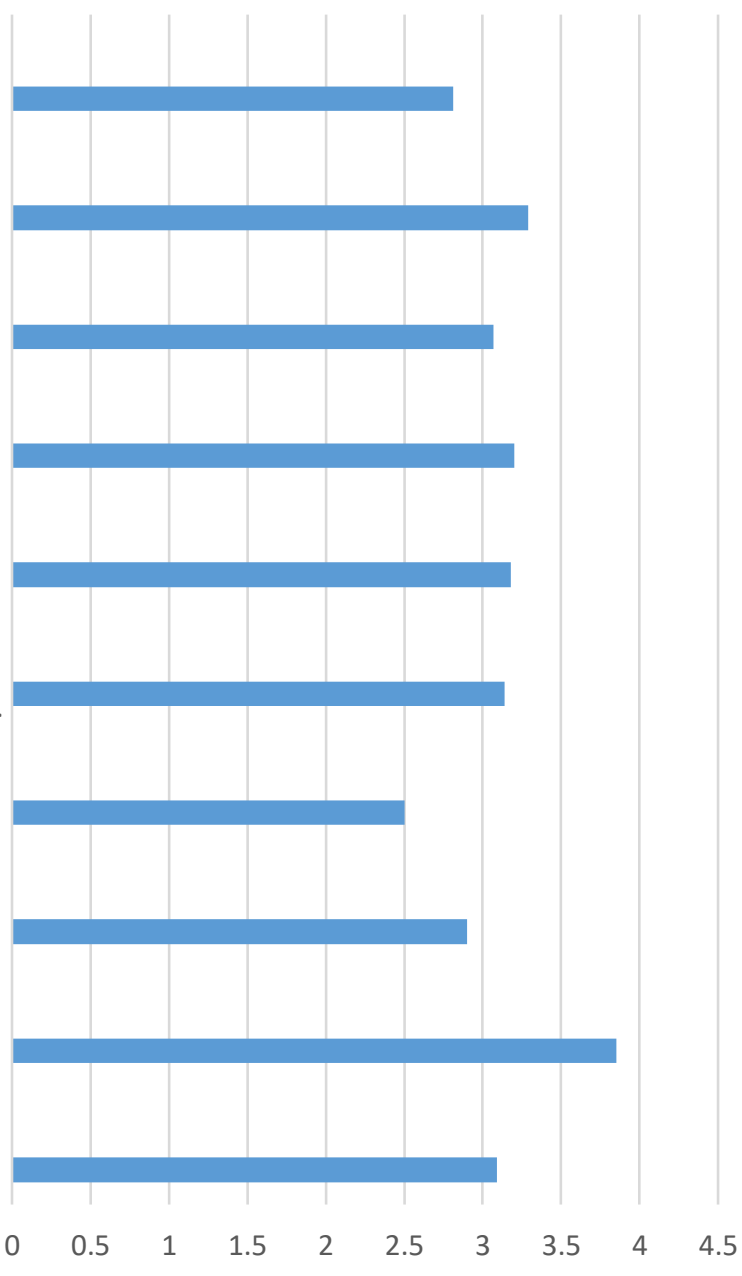

Pernyataan rata-rata kecemasan paling banyak pada siswa yaitu "saya merasa bahwa saya perlu belajar lebih giat untuk ujian sistem persamaan linear dua variabel dari pada ujian materi mata pelajaran lainnya" dengan nilai $M=3.85, S D=1.148$. Sedangkan pernyataan rata-rata kecemasan paling sedikit pada siswa yaitu "saat belajar untuk ujian materi sistem persamaan linear dua variabel, saya menunjukan perilaku cemas" ( $M=2.50, S D=1.152)$. Sistem persamaan linear dua variabel merupakan turunan materi dari aljabar. Ketika siswa memiliki keterampilan yang rendah dan memiliki pandangan negatif mengenai ujian yang akan berlangsung maka dapat menimbulkan kecemasan pada siswa.

Hal ini juga disampaikan Ramirez et al., (2018) bahwa ujian matematika yang sulit merupakan pemicu kecemasan siswa. Dalam pembelajaran di kelas, aljabar merupakan salah satu materi penyebab kecemasan siswa. Hal ini sesuai dengan penelitian yang dilakukan oleh Adams \& Holcomb (1986) bahwa terdapat hubungan negatif antara kecemasan yang tinggi dan keterampilan aljabar pada siswa. Hal ini 
menjelaskan semakin tinggi kecemasan siswa maka semakin rendah keterampilan aljabar siswa dan sebaliknya.

\section{Tabel 3. Faktor Lingkungan}

Pernyataan

Mean SD Rank

$\begin{array}{lllll}\text { Saya merasa bahwa saya tidak akan bisa memahami materi } & 2.31 & 1.132 & 7\end{array}$ sistem persamaan linear dua variabel tidak peduli sejauh mana saya berusaha.

Saya merasa orang lain lebih mempunyai kemampuan berpikir $\quad \begin{array}{llll}3.30 & 1.190 & 1\end{array}$
matematis dan logis dari pada saya.

$\begin{array}{llll}\text { Orang tua dan/ atau teman saya bercerita kesusahan dan frustasi } & 2.29 & 1.179 & 8\end{array}$ mereka terhadap materi sistem persamaan linear dua variabel.

$\begin{array}{lllll}\text { Saya bergantung kepada orang lain dalam situasi sehari-hari } & 2.35 & 1.124 & 6\end{array}$ yang menyangkut materi sistem persamaan linear dua variabel. $\begin{array}{lllll}\text { Dalam materi sistem persamaan linear dua variabel, saya } & 2.92 & 1.041 & 2\end{array}$ merasa pilihan jawaban hanya benar atau salah dan kecil kemungkinan ada jawaban lain.

$\begin{array}{llll}\text { Saya mempunyai guru matematika yang tidak saya suka karena } & 1.91 & 1.180 & 9\end{array}$ satu atau alasan lain.

Saya merasa cemas mengenai kemampuan materi sistem $2.65 \quad 1.239 \quad 4$ persamaan linear dua variabel orang lain dan akan membandingkan dengan kemampuan saya.

Meskipun saya cukup berbakat dalam beberapa hal, saya $2.76 \quad 1.246 \quad 3$ merasa bakat tersebut tidak membantu dalam materi sistem persamaan linear dua variabel.

$\begin{array}{lllllll}\text { Saya pernah dihukum atau dipermalukan dalam kelas } & 1.30 & 0.735 & 10\end{array}$ matematika karena tidak memahami materi sistem persamaan linear dua variabel.

$\begin{aligned} & \text { Saya merasa bahwa saya tidak pernah benar-benar memahami } \\ & \text { materi sistem persamaan linear dua variabel dan saya hanya }\end{aligned}$
pura-pura memahaminya.

Tabel 3 memberikan ringkasan hasil kuesioner siswa pada faktor lingkungan. Secara umum siswa setuju bahwa orang lain lebih mempunyai kemampuan berpikir matematis dan logis dari pada mereka ( $\mathrm{M}$ $=3.30, \mathrm{SD}=1.190)$. Hal ini diperlihatkan ketika pembelajaran berlangsung, siswa dengan kemampuan berpikir matematis dan logis lebih cepat paham dan mendapat nilai yang memuaskan. Situasi ini secara tidak langsung membuat siswa membandingkan dirinya dengan temannya yang ditunjukan pada 
pernyataan "saya merasa cemas mengenai kemampuan materi sistem persamaan linear dua variabel orang lain dan akan membandingkan dengan kemampuan saya." ( $M=2.65, S D=1.239)$.

Sejalan dengan Finlayson (2014) yang mengatakan bahwa siswa merasa lebih cemas ketika melihat teman lainnya mampu mengerjakan matematika dengan baik serta memiliki pengetahuan yang lebih banyak mengenai materi matematika dibandingkan dirinya sendiri. Rasa khawatir yang dialami siswa ini menyebabkan kesulitan tersendiri dalam pemahaman pembelajaran. Hal ini tentunya dapat menjadi kesulitan dalam mengerjakan matematika pada siswa sehingga berakibat pada hasil belajar, prestasi, kemampuan, dan cara pandang terhadap matematika (Beilock \& Maloney, 2015). Kesulitan tersebut membuat siswa bingung untuk menemukan jawaban yang benar, hal ini ditunjukan pada pernyataan "dalam materi sistem persamaan linear dua variabel, saya merasa pilihan jawaban hanya benar atau salah dan kecil kemungkinan ada jawaban lain." ( $M=2.92, S D=1.041)$. Sejalan dengan pendapat Finlayson (2014) bahwa ketika siswa mengerjakan ujian, mereka meyakini bahwa hanya terdapat satu cara untuk menemukan jawaban benar dan tidak ada jawaban lain selain benar atau salah, kondisi ini membuat siswa menjadi tertekan karena bingung bagaimana mendapat jawaban yang benar sementara tidak ada yang membantunya. Pernyataan "saya merasa bahwa saya tidak pernah benar-benar memahami materi sistem persamaan linear dua variabel dan saya hanya pura-pura memahaminya." (M $=2.43, \mathrm{SD}=1.270$ ) dapat menjadi penyebab kebingungan siswa dalam mengerjakan ujian . 


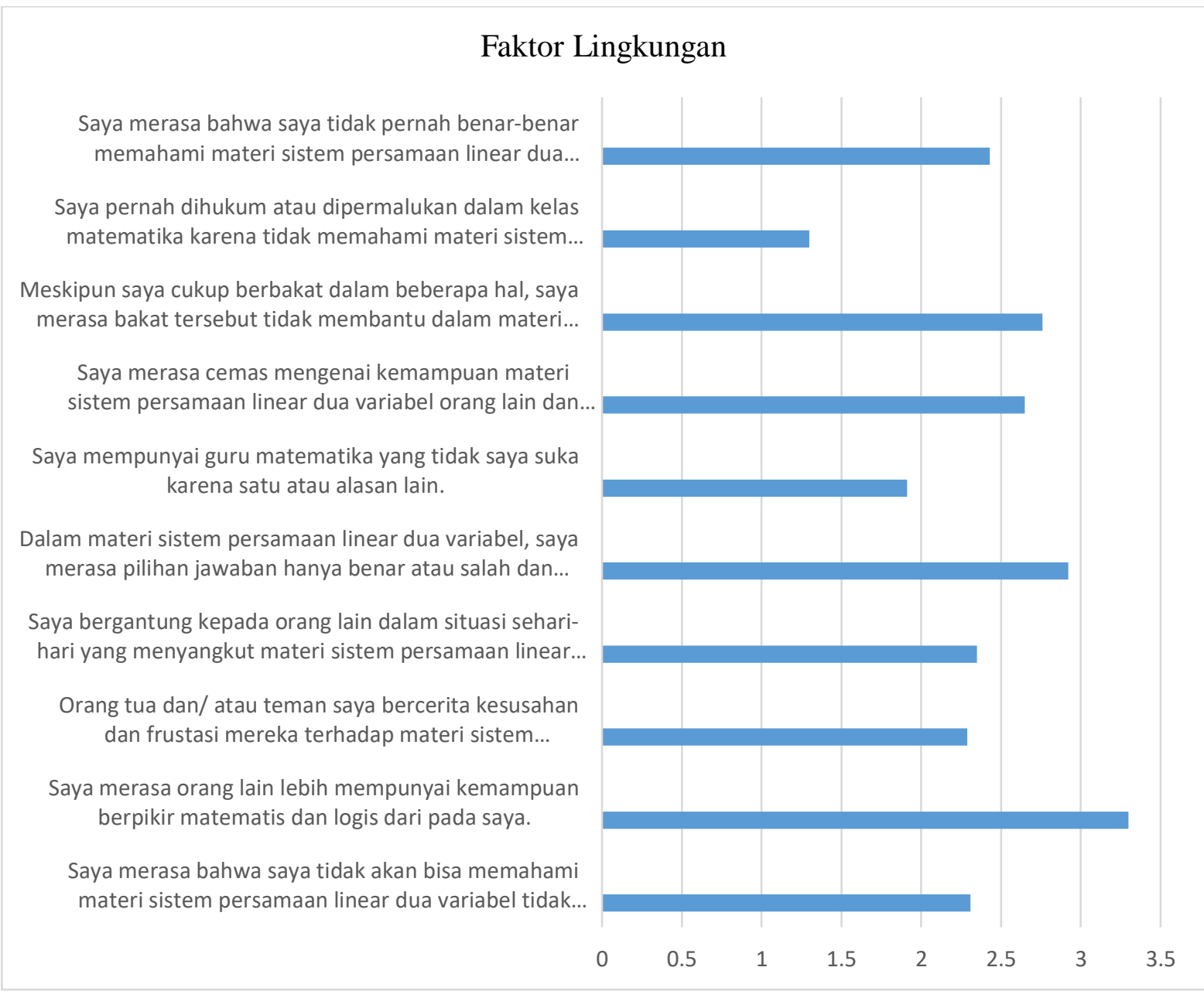

Pernyataan rata-rata kecemasan paling banyak pada siswa yaitu "saya merasa orang lain lebih mempunyai kemampuan berpikir matematis dan logis dari pada saya" dengan nilai ( $M=3.30, S D=1.190)$. Sedangkan pernyataan rata-rata kecemasan paling sedikit pada siswa yaitu "saya pernah dihukum atau dipermalukan dalam kelas matematika karena tidak memahami materi sistem persamaan linear dua variabel." ( $(M=1.30, S D=0.735)$. Pengalaman menyedihkan merupakan penyebab umum kecemasan siswa dalam pembelajaran di kelas. Pernyataan ini sesuai dengan Namkung et al., (2019) bahwa pengalaman menyedihkan dan kegagalan di masa lalu dapat menjadi penyebab terjadinya kecemasan siswa dalam pembelajaran di kelas. Pengalaman negatif ini dapat menimbulkan pandangan negatif siswa terhadap matematika sehingga menimbulkan penghindaran terhadap matematika yang dapat mempengaruhi hasil belajar siswa. Hal sesuai diungkapkan oleh Beilock \& Maloney (2015) bahwa pengalaman negatif dan pandangan negatif dapat menyebabkan kesulitan tersendiri bagi siswa sehingga mempengaruhi hasil belajar siswa dikelas.

\section{Kesimpulan}

Pada hasil survey ditemukan beberapa siswa mengalami beberapa ciri-ciri atau gejala kecemasan yang mengindikasikan bahwa terdapat kecemasan siswa dalam menyelesaikan masalah sistem 
persamaan linear dua variabel pada kelas virtual. Kecemasan paling banyak dialami siswa pada faktor penilaian. Kecemasan tertinggi ditunjukan ketika dilaksanakannya ujian sistem persamaan linear dua variabel yang dikarenakan kurangnya persiapan ujian dan pemahaman siswa pada materi tersebut. Hal serupa juga terjadi pada faktor emosional bahwa siswa kesulitan mengontrol nilainya pada materi sistem persamaan linear dua variabel dikarenakan kurangnya pemahaman konsep. Kurangnya pemahaman materi siswa pada kelas virtual sangat mungkin terjadi mengingat sistem pembelajaran kelas virtual yang fleksibel sehingga dibutuhkan kesadaran diri pada diri siswa dalam memahami, mempelajari dan mengikuti pembelajaran di kelas virtual.

Kecemasan lainnya ditemukan pada faktor lingkungan yakni rasa tidak percaya diri siswa pada kemampuannya dan merasa bahwa orang lain memiliki kemampuan matematis yang lebih logis. Pandangan negatif ini tidak baik untuk siswa karena dapat mempengaruhi proses berpikirnya terhadap penyelesaian matematika sehingga pada titik tertentu dapat menyebabkan kesulitan tersendiri pada siswa yang dapat menimbulkan kecemasan. Dorongan dari orang tua dan guru merupakan hal yang diperlukan siswa. Guru tidak perlu membandingkan siswa dengan siswa lainnya yang lebih cerdas karena dapat membuat siswa merasa rendah diri dan tidak percaya dengan kemampuannya. Selain itu, orang tua juga tidak perlu menuntut anak agar mendapat nilai sempurna dan tidak perlu membandingkannya dengan anak-anak lainnya. Guru dan orang tua perlu bekerja sama untuk memberikan dorongan positif dan motivasi pada siswa agar bisa mengurangi kecemasan pada dirinya. Di sisi lain siswa juga harus bersemangat untuk belajar agar mengurangi rasa tidak percaya diri dalam dirinya.

Meskipun begitu, kecemasan merupakan hal wajar yang dialami setiap manusia pada situasi atau kondisi tertentu. Kecemasan dapat membawa dampak positif atau dampak negatif tergantung seberapa besar kecemasan yang dimiliki. Kecemasan dengan porsi sedikit dapat memberikan dorongan secara tidak langsung pada diri siswa sehingga memberikan hasil yang positif sebaliknya kecemasan berlebihan dapat membawa hasil yang negatif. Maka dari itu diperlukan pengontrolan diri untuk mengurangi kecemasan seperti memahami materi dengan baik, selalu mengikuti pembelajaran di kelas virtual, serta mampu mengatur waktu dengan baik dalam pembelajaran kelas virtual. Perlunya lingkungan positif dari diri sendiri, orang tua dan guru sehingga dapat meminimalisir kecemasan siswa.

\subsection{Penelitian yang akan datang}

Penelitian ini masih perlu dikembangkan dengan penelitian-penelitian selanjutnya. Penelitian selanjutnya dapat dikombinasikan dengan penelitian kualitatif agar dapat merepresentasikan hasil penelitian secara maksimal. Penelitian kualitatif memberikan deskripsi gambaran mengenai hal-hal yang tidak dapat dijelaskan dengan angka-angka sehingga dengan mengkombinasikan penelitian kuantitatif dan penelitian kualitatif dapat memperoleh pemahaman yang lebih mendalam serta dapat memberikan informasi mengenai penelitian yang dilakukan secara maksimal.

Subjek penelitian ini sangat terbatas pada daerah perkotaan yaitu Jakarta, Bogor, Depok, Tangerang dan Bekasi yang mana memiliki kualitas internet memadai. Penelitian selanjutnya dapat dilakukan di pedesaan atau daerah terpencil untuk mengetahui kecemasan siswa pada kelas virtual. Adanya perbedaan kualitas internet, teknologi, budaya dan sumber daya manusia dapat menjadi 
pertimbangan untuk dilakukannya penelitian yang akan datang. Pengukuran kecemasan akan lebih baik jika menggunakan gabungan wawancara dan survey. Wawancara digunakan guna memperoleh gambaran lebih dalam mengenai kecemasan yang dialami siswa selama pembelajaran pada kelas virtual. Sehingga dengan menggabungkan teknik wawancara dan survey akan mendapatkan gambaran yang lebih maksimal mengenai kecemasan siswa pada kelas virtual.

\section{Identitas Penulis}

Evi Sri Hastuti

Email: evi.sri.hastuti.students@uhamka.ac.id

ORCID ID: https://orcid.org/0000-0003-2718-7496

Khoerul Umam

Email: khoerul.umam@uhamka.ac.id

ORCID ID: https://orcid.org/0000-0003-3853-7025

Lawrence Eclarin

Email: mathdept@mmsu.edu.ph

Krisna Satrio Perbowo

Email: k.perbowo@warwick.ac.id

\section{Konflik Kepentingan}

Penulis menyatakan tidak ada konflik kepentingan

\section{Citation information}

Cite this article as: Hastuti, S., H., Umam, K., Eclarin, L,.\& Perbowo, K., S., 2021. K Kecemasan Siswa Dalam Menyelesaikan Masalah Modelling Matematika Pada Praktek Kelas Virtual. International Journal of Progressive Mathematics Education. 1(1).64-84. https://doi.org/10.22236/ijopme.v1i1.6914.

\section{Referensi}

Aarnos, E., \& Perkkilä, P. (2012). Early Signs of Mathematics Anxiety? Procedia - Social and Behavioral Sciences, 46(2003), 1495-1499. https://doi.org/10.1016/i.sbspro.2012.05.328

Adams, N. A., \& Holcomb, W. R. (1986). Analysis of The Relationship Between Anxiety About Mathematics and Performance. $\quad$ Psychological Reports, $\quad$ 59, 943948. https://doi.org/https://doi.org/10.2466\%2Fpro.1986.59.2.943

Ashcraft, M. H. (2002). Math Anxiety: Personal, Educational, and Cognitive Consequences. Current Directions in Psychological Science, 11(5), 181-185. https://doi.org/https://doi.org/10.1111/1467-8721.00196

Beatrice Ghirardini. (2015). E-Learning Methodologies. The International Journal of Critical Cultural Studies, 13(2), 13-25. https://doi.org/10.18848/2327-0055/cgp/v13i02/43766

Beilock, S. L., \& Maloney, E. A. (2015). Math Anxiety: A Factor in Math Achievement Not to Be Ignored. Policy Insights from the Behavioral and Brain Sciences, 2(1), 4-12. https://doi.org/10.1177/2372732215601438 
Dhawan, S. (2020). Online Learning: A Panacea in the Time of COVID-19 Crisis. Journal of Educational Technology Systems, 0(0), 1-18. https://doi.org/10.1177/0047239520934018

Finlayson, M. (2014). Addressing Math Anxiety in The Classroom. Improving Schools, 17(1), 99115. https://doi.org/10.1177/1365480214521457

Gallagher, J. P. (1979). Cognitive/ Information Processing Psychology And Instruction: Reviewing Recent Theory And Practice. Instructional Science, 8, 393-414. https://doi.org/10.1007/BF00117014

Gautreau, C., Brye, M. V. V., \& Lunceford, C. (2016). Mathematics-related anxiety and attitudes: examining the impact among Latina preservice teachers. Journal of Latinos and Education, 15(1), 2638. https://doi.org/10.1080/15348431.2015.1045146

Hanna, D., \& Dempster, M. (2009). The effect of statistics anxiety on students' predicted and actual test scores. Irish Journal of Psychology, 30(3-4), 201-209. https://doi.org/10.1080/03033910.2009.10446310

Harari, R. R., Vukovic, R. K., \& Bailey, S. P. (2013). Mathematics Anxiety in Young Children: An Exploratory Study. Journal of Experimental Education, 81(4), 538-555. https://doi.org/10.1080/00220973.2012.727888

Hox, J. J., \& Boeije, H. R. (2005). Data Collection, Primary vs. Secondary. In Encyclopedia of Social Measurement (Vol. 1, pp. 593-599). elshevier. https://doi.org/10.1016/B0-12-369398-5/00041-4

Jameson, M. M. (2014). Contextual Factors Related to Math Anxiety in Second-Grade Children. Journal of Experimental Education, 82(4), 518-536. https://doi.org/10.1080/00220973.2013.813367

Kargar, M., Tarmizi, R. A., \& Bayat, S. (2010). Relationship between Mathematical Thinking, Mathematics Anxiety and Mathematics Attitudes among University Students. Procedia - Social and Behavioral Sciences, 8, 537-542. https://doi.org/10.1016/j.sbspro.2010.12.074

Lee, K.-T., \& Duncan-Howell, J. (2007). How Do We Know E-Learning Works? Or Does it? E-Learning and Digital Media, 4(4), 482-496. https://doi.org/10.2304/elea.2007.4.4.482

Mann, L. C., \& Walshaw, M. (2019). Mathematics Anxiety in Secondary School Female Students: Issues, Influences and Implications. New Zealand Journal of Educational Studies, 54(1), 101120. https://doi.org/10.1007/s40841-019-00126-3

Moore, J. L., Dickson-Deane, C., \& Galyen, K. (2011). E-Learning, online learning, and distance learning environments: Are they the same? Internet and Higher Education, 14(2), 129135. https://doi.org/10.1016/j.iheduc.2010.10.001

Namkung, J. M., Peng, P., \& Lin, X. (2019). The Relation Between Mathematics Anxiety and Mathematics Performance Among School-Aged Students: A Meta-Analysis. Review of Educational Research, 89(3), 459-496. https://doi.org/10.3102/0034654319843494

Nurdianti, D., Rohaeti, E. E., \& Senjayawati, E. (2019). Analisis Kemampuan Koneksi Matematik Siswa Kelas XII Madrasah Aliyah Kota Cimahi Pada Materi SPLDV. Jurnal On Education, 01(02), 126-131.

Nyroos, M., Jonsson, B., Korhonen, J., \& Eklöf, H. (2015). Children's mathematical achievement and how it relates to working memory, test anxiety and self-regulation: A person-centred approach. Education Inquiry, 6(1). https://doi.org/10.3402/edui.v6.26026

Oktawirawan, D. H. (2020). Faktor Pemicu Kecemasan Siswa dalam Melakukan Pembelajaran Daring di Masa Pandemi Covid-19. Jurnal Ilmiah Universitas Batanghari Jambi, 20(2), 541. https://doi.org/10.33087/jiubj.v20i2.932 
Ramirez, G., Hooper, S. Y., Kersting, N. B., Ferguson, R., \& Yeager, D. (2018). Teacher Math Anxiety Relates to Adolescent Students' Math Achievement. AERA Open, 4(1), 233285841875605. https://doi.org/10.1177/2332858418756052

Roux, l., \& Nagel, L. (2018). Seeking the best blend for deep learning in a flipped classroom - viewing student perceptions through the Community of Inquiry lens.

Rozgonjuk, D., Kraav, T., Mikkor, K., Orav-Puurand, K., \& Täht, K. (2020). Mathematics anxiety among STEM and social sciences students: the roles of mathematics self-efficacy, and deep and surface approach to learning. International Journal of STEM Education, 7(1). https://doi.org/10.1186/s40594-020-00246-z

Sahin, I. (2007). Predicting student satisfaction in distance education and learning environments. Turkish Online Journal of Distance Education. https://doi.org/10.17718/tojde.70222

Selvanathan, M., Hussin, N. A. M., \& Azazi, N. A. N. (2020). Students Learning Experiences During COVID-19: Work From Home Period in Malaysian Higher Learning Institutions. Teaching Public Administration, $0(0)$, 1-10. https://doi.org/10.1177/0144739420977900

Şengül, S., \& Dereli, M. (2010). Does instruction of "Integers" subject with cartoons effect students' mathematics anxiety? Procedia - Social and Behavioral Sciences, 2(2), 21762180. https://doi.org/10.1016/j.sbspro.2010.03.302

Sevindir, H. K., Yazici, C., \& Yazici, V. (2014). Mathematics Anxiety of Secondary School Students: A Case Study for Kocaeli Area. Procedia - Social and Behavioral Sciences, 152, 630636. https://doi.org/10.1016/.sbspro.2014.09.254

Sherman, B. F., \& Wither, D. P. (2003). Mathematics anxiety and mathematics achievement. Mathematics Education Research Journal, 15(2), 138-150. https://doi.org/10.1007/BF03217375

Sloan, T. R. (2010). A Quantitative and Qualitative Study of Math Anxiety Among Preservice Teachers. Educational Forum, 74(3), 242-256. https://doi.org/10.1080/00131725.2010.483909

Suárez-Pellicioni, M., Núñez-Peña, M. I., \& Colomé, À. (2016). Math anxiety: A review of its cognitive consequences, psychophysiological correlates, and brain bases. Cognitive, Affective and Behavioral Neuroscience, 16(1), 3-22. https://doi.org/10.3758/s13415-015-0370-7

Umam, K., Nusantara, T., Parta, I. N., Hidayanto, E., \& Mulyono, H. (2019). An application of flipped classroom in mathematics teacher education programme. International Journal of Interactive Mobile Technologies, 13(3). https://doi.org/10.3991/ijim.v13i03.10207

Vitasari, P., Herawan, T., Wahab, M. N. A., Othman, A., \& Sinnadurai, S. K. (2010). Exploring Mathematics Anxiety among Engineering students. Procedia - Social and Behavioral Sciences, 8, 482489. https://doi.org/10.1016/j.sbspro.2010.12.066

Wahid, S. N. S., Yusof, Y., \& Razak, M. R. (2014). Math Anxiety among Students in Higher Education Level. Procedia - Social and Behavioral Sciences, 123, 232-237. https://doi.org/10.1016/isbspro.2014.01.1419

Winardi, M. P. A., Halini, \& Hamdani. (2019). Hubungan Kecemasan Matematika Dan Kemampuan Komunikasi Matematis Siswa Kelas IX Pada Materi SPLDV. Jurnal Pendidikan Dan Pembelajaran Khatulistiwa, 8(3).

Winarso, W., \& Haqq, A. A. (2019). Psichological disposition of student; Mathematics anxiety vesus happines learning on the level education. International Journal of Trends in Mathematics Education Research, 2(1), 19. https://doi.org/10.33122/ijtmer.v2i1.32 
International Journal of Progressive Mathematics Education

https://doi.org/10.22236/ijopme.v1i1.6914

Zientek, L. R., Yetkiner, Z. E., \& Thompson, B. (2010). Characterizing the mathematics anxiety literature using confidence intervals as a literature review mechanism. Journal of Educational Research, 103(6), 424438. https://doi.org/10.1080/00220670903383093 